MaPan : Jurnal Matematika dan Pembelajaran

p-ISSN: 2354-6883 ; e-ISSN: 2581-172X

Volume 4, Nomor 1, Juni 2016

\title{
PEMBELAJARAN BERDASARKAN MASALAH SUATU UPAYA UNTUK MENGEMBANGKAN KEMAMPUAN PEMAHAMAN DAN REPRESENTASI MATEMATIK SISWA
}

\author{
Andi Ika Prasasti Abrar \\ Fakultas Tarbiyah dan Keguruan UIN Alauddin Makassar \\ Kampus II: Jalan H. M. Yasin Limpo Nomor 36 Samata-Gowa \\ E-mail: asty_math03@yahoo.co.id
}

\begin{abstract}
Abstrak
Tulisan ini membatasi pada ciri-ciri khusus, tujuan pembelajaran, hasil belajar, tahapan (sintaks) pembelajaran berdasarkan masalah, dan kaitan pembelajaran berdasarkan masalah dengan kemampuan pemahaman dan representasi matematik. Pembelajaran berdasarkan masalah merupakan salah satu pembelajaran yang dapat merangsang pola berpikir siswa dalam situasi berorientasi masalah, termasuk didalamnya belajar bagaimana belajar. Oleh karena itu, pembelajaran berdasarkan masalah memberikan kesempatan yang cukup bagi siswa untuk dapat melatih dan mengembangkan kemampuan pemahaman dan representasi matematiknya.
\end{abstract}

Kata Kunci: Pembelajaran Berdasarkan Masalah, Kemampuan Pemahaman, Representasi Matematik

$\mathrm{P}$ engembangan konsep dalam materi matematika seyogianya tidak dibatasi pada topik yang sedang dibahas saja, melainkan dikaitkan pula dengan topik-topik yang relevan bahkan dengan bidang studi lain jika memungkinkan secara terpadu. Pembelajaran matematika yang terpadu memfokuskan pada pendekatan pembelajaran antar topik bahkan jika memungkinkan antar disiplin. Karena secara umum, para siswa sulit untuk berpikir secara parsial tentang apa yang mereka pelajari, tetapi mereka cenderung memandang "dunia sekitar" secara holistik.

Pembelajaran matematika diharapkan berakhir dengan sebuah pemahaman siswa yang komprehensif dan holistik (lintas topik bahkan lintas bidang studi jika memungkinkan) tentang materi yang telah disajikan. Pemahaman siswa yang dimaksud tidak sekedar memenuhi tuntutan tujuan pembelajaran matematika secara substantive saja, namun diharapkan pula muncul "efek iringan" dari pembelajaran matematika tersebut. Efek iringan yang dimaksud antara lain :

a. Lebih memahami keterkaitan antara satu topik matematika dengan topik matematika yang lainnya. 
b. Lebih menyadari akan penting dan strategisnya matematika bagi bidang lain.

c. Lebih memahami peranan matematika dalam kehidupan manusia.

d. Lebih mampu berpikir logis, kritis dan sistematis.

e. Lebih kreatif dan inovatif dalam mencari solusi pemecahan sebuah masalah.

f. Lebih peduli pada lingkungan sekitarnya.

Ketercapaian dua sasaran pembelajaran matematika secara substansif dan efek iringannya akan tercapai manakala siswa diberi kesempatan yang seluas-luasnya untuk belajar matematika (doing math). Dengan demikian, dalam proses belajar mengajar matematika kegiatan pengajaran perlu diubah menjadi kegiatan pembelajaran. Teknik mengajar yang baik harus diganti dengan teknik belajar yang baik.

Belajar matematika tidak sekedar learning to know, melainkan harus ditingkatkan meliputi learning to do, learning to be, hingga learning to live together. Kendati pun antara kata pengajaran dengan pembelajaran bermakna hampir sama, namun esensinya relatif berbeda. Bila dalam pengajaran matematika, guru lebih banyak menyampaikan sejumlah ide atau gagasangagasan matematika. Sementara dalam pembelajaran matematika siswa mendapat porsi lebih banyak dibandingkan dengan guru, bahkan mereka harus dominan dalam kegiatan belajar mengajar.

Dengan mengaktifkan siswa seperti ini akan merangsang pola pikirnya dalam situasi berorientasi masalah termasuk didalamnya belajar bagaimana belajar. Dengan memberikan kesempatan yang seluas-luasnya kepada siswa pada saat belajar (mengaktifkan siswa) diharapkan dapat membantu siswa mengembangkan kemampuan berpikir, memecahkan masalah, dan keterampilan intelektual; belajar berbagai peran orang dewasa melalui pelibatan mereka dalam pengalaman nyata atau simulasi; dan menjadi pebelajar yang otonom dan mandiri.

Hal tersebut sejalan dengan hasil penelitian Asup Suparlan (2004) yang menemukan bahwa kemampuan pemahaman dan representasi matematik siswa SMP yang diperoleh melalui pembelajaran berbasis masalah lebih baik dibandingkan dengan pembelajaran klasikal ekspositori, selain itu siswa bersikap positif dan guru memberikan pandangan yang positif, serta siswa aktif selama proses pembelajaran berlangsung, dengan kata lain bahwa pembelajaran berbadasarkan masalah menciptakan suasana belajar yang lebih kondusif dibandingkan dengan pembelajaran biasa dalam hal pengembangan 
Kemampuan pamahaman dan representasi matematik, membangun sikap yang positif, dan pemberian kesempatan siswa yang lebih luas dalam menuangkan ide/gagasan matematika selama proses pembelajaran berlangsung untuk mengkonstruk pemahamannya.

\section{PEMBAHASAN}

Pembelajaran berdasarkan masalah atau Problem Based Instuction (PBI) adalah salah satu pembelajaran yang dapat merangsang pola berpikir siswa dalam situasi berorientasi masalah, termasuk didalamnya belajar bagaimana belajar. Model ini juga dikenal dengan nama lain seperti project-based teaching (Pembelajaran Proyek), experienced based education (Pendidikan berdasarkan Pengalaman), authentic learning (Belajar Autentik), dan anchored instruction (Pembelajaran Berakar Pada Kehidupan Nyata).

Berbeda dengan model pembelajaran langsung, yang menekankan pada presentase ide-ide atau demonstrasi keterampilan oleh guru, peran guru dalam model PBI adalah menyajikan masalah, mengajukan pertanyaan, dan memfasilitasi penyelidikan dan dialog. Lebih penting lagi adalah bahwa guru melakukan scaffolding suatu kerangka dukungan yang memperkaya inkuiri dan pertumbuhan intelektual. PBI tidak dapat terjadi tanpa guru mengembangkan lingkungan kelas yang memungkinkan terjadinya pertukaran ide secara terbuka. Dalam hal ini banyak kesamaan antara PBI dengan diskusi kelas.

\section{Ciri-ciri Khusus PBI}

a. Pengajuan pertanyaan atau masalah

Pembelajaran berdasarkan masalah mengorganisasikan pengajaran disekitar pertanyaan dan masalah yang dua-duanya secara social penting dan secara pribadi bermakna untuk siswa. Mereka mengajukan situasi kehidupan nyata autentik, menghindari jawaban sederhana dan memungkinkan adanya berbagai macam solusi untuk situasi itu.

b. Berfokus pada keterkaitan antar disiplin

Meskipun PBI mungkin berpusat pada mata pelajaran tertentu (IPA, Matematika, Ilmu-ilmu sosial) masalah yang akan diselidiki telah dipilih benar-benar nyata agar dalam pemecahannya siswa meninjau masalah itu dari banyak mata pelajaran. 


\section{c. Penyelidikan autentik}

PBI mengharuskan siswa melakukan penyelidikan autentik untuk mencari penyelesaian nyata terhadap masalah nyata. Mereka menganalisis dan mendefinisikan masalah, membuat ramalan, mengumpulkan informasi, melakukan eksperimen jika diperlukan dan merumuskan kesimpulan. Metode penyelidikan yang digunakan bergantung pada masalah yang dipelajari.

d. Menghasilkan karya dan peragaan

PBI menuntut siswa untuk menghasilkan produk tertentu dalam bentuk karya nyata dan menjelaskan bentuk penyelesaian masalah yang mereka temukan. Produk tersebut dapat berupa laporan. Karya nyata dan peragaan seperti yang akan dijelaskan kemudian, direncanakan oleh siswa untuk didemonstrasikan kepada teman-temannya yang lain tentang apa yang mereka telah pelajari.

e. Kerja sama

Seperti halnya dengan model pembelajaran kooperatif, PBI dicirikan oleh siswa yang bekerja sama, paling sering secara berpasangan atau dalam kelompok kecil. Bekerja sama memberikan motivasi untuk secara berkelanjutan terlibat dalam tugas-tugas kompleks dan memperbanyak peluang untuk berbagi inkuiri dan dialog dan untuk mengembangkan keterampilan sosial dan keterampilan berpikir.

\section{Tujuan Pembelajaran dan Hasil Belajar}

PBI tidak dirancang untuk membantu guru memberikan informasi sebanyak-banyaknya kepada siswa. PBI utamanya dikembangkan untuk membantu siswa memgembangkan kemampuan berpikir, pemecahan masalah, dan keterampilan intelektual; belajar berbagai peran orang dewasa melalui pelibatan mereka dalam pengalaman nyata; dan menjadi pebelajar yang mandiri.

\section{Keterampilan Berpikir dan Keterampilan Pemecahan Masalah}

Berbagai macam ide telah digunakan untuk memberikan cara seseorang berpikir. Tapi apa sebenarnya yang terlibat dalam proses berpikir? Kebanyakan definisi yang telah dikemukakan memerikan proses-proses intelektual abstrak antara lain sebagai berikut:

a. Berpikir adalah proses yang melibatkan koperasi mental seperti induksi, deduksi, klasifikasi, dan penalaran. 
b. Berpikir adalah proses secara simbolik menyatakan melalui bahasa obyek nyata dan kejadian-kejadian serta penggunaan pernyataan simbolik untuk menemukan prinsip-prinsip esensial tentang objek dan kejadian itu.

c. Berpikir adalah kemampuan untuk menganalisis, mengkritik, dan mencapai kesimpulan berdasar pada inferensi atau pertimbangan yang saksama.

Johnson (2002) mengemukakan bahwa keterampilan berpikir sebagai realitas berpikir tingkat tinggi adalah aktifitas mental yang menunjukkan eksistensi keaslian dan wawasan atau pengertian yang mendalam. Oleh karena itu, keterampilan berpikir ini mengantarkan peserta didik untuk mempelajari permasalahan-permasalahan secara sistematik, menemukan cara mengorganisir permasalahan, memformulasi pertanyaan yang inovatif, dan membangun solusi yang original. Hal tersebut memberi kekuatan kepada siswa untuk melakukan dan menemukan pemecahan terhadap masalah yang dihadapinya. Pemecahan masalah merupakan hal pokok yang harus dilakukan di dalam memberikan solusi terhadap fenomena-fenomena yang erat kaitannya dengan permasalahan matematik.

Menurut Suriadi, dkk (TIM MKPBM, 2001) menemukan bahwa pemecahan masalah dalam matematika merupakan salah satu kegiatan matematik yang dianggap penting, baik oleh para guru maupun siswa disemua tinggkatan. Akan tetapi hal tersebut, masih dianggap sebagai bagian yang paling sulit dalam matematika baik bagi siswa dalam mempelajarinya maupun bagi guru yang mengajarkannya.

Sebagian besar masalah yang dijumpai siswa di sekolah mungkin memerlukan membaca dengan saksama dan sejumlah pemikiran, tetapi sedikit kreatifitas.

\section{Pemodelan Peranan Orang Dewasa}

Resnick memberikan rasional tentang bagaimana bagaimana PBI membantu siswa untuk berkinerja dalam situasi kehidupan nyata dan belajar pentingnya peran orang dewasa.

Pandangan Resnick tersebut memberikan alasan yang kuat untuk PBI. Dia mengemukakan bahwa bentuk pembelajaran ini penting untuk menjembatani gab antara pembelajaran sekolah formal dengan aktivitas mental yang lebih praktis yang dijumpai di luar sekolah. 


\section{Pebelajar yang Otonom dan Mandiri}

PBI berusaha membantu siswa menjadi pebelajar yang mandiri dan otonom. Dengan bimbingan guru yang secara berulang-ulang mendorong dan mengarahkan mereka untuk mengajukan pertanyaan, mencari penyelesaian terhadap masalah nyata oleh mereka sendiri, siswa belajar untuk menyelesaikan tugas-tugas itu secara mandiri dalam hidupnya kelak.

\section{Sintaks PBI}

PBI terdiri dari 5 tahapan yang dimulai dari guru memperkenalkan siswa dengan suatu situasi masalah dan diakhiri dengan penyajian dan analisis hasil kerja siswa. Jika jangkauan masalahnya sedang-sedang saja, kelima tahapan tersebut mungkin dapat diselesaikan dalam 2 sampai 3 kali pertemuan. Namun untuk masalah yang kompleks mungkin akan membutuhkan waktu yang lama untuk menyelesaikannya. Kelima tahapan tersebut disajikan dalam tabel berikut:

Tabel 1. Sintaks Problem Based Instuction (PBI)

\begin{tabular}{ll}
\hline \multicolumn{1}{c}{ Tahap } & \multicolumn{1}{c}{ Tingkah Laku Guru } \\
\hline Tahap - 1 & Guru menjelaskan tujuan pembelajaran, \\
Orientasi siswa kepada & $\begin{array}{l}\text { memotivasi siswa terlibat pada aktivitas } \\
\text { pemecahan masalah yang disediakan. }\end{array}$ \\
masalah & Guru membantu siswa mendifinisikan \\
Tahap - 2 & dan mengorganisasikan tugas belajar \\
Mengorganisasi siswa & yang berhubungan dengan masalah \\
untuk belajar & tersebut. \\
& Guru mendorong siswa untuk \\
Tahap - 3 & mengumpulkan informasi yang \\
Membimbing & sesuai,melaksanakan eksperimen jika \\
penyelidikan individual & diperlukan, untukmendapatkan \\
maupun kelompok & penjelasan dan pemecahan masalah. \\
& Guru membantu siswa dalam \\
Tahap - 4 & merencanakan dan menyiapkan karya \\
Mengembangkan dan & yang sesuai (laporan). \\
menyajikan hasil karya & Guru membantu siswa untuk melakukan \\
Tahap -5 & refleksi atau evalusi terhadap \\
Menganalisis dan & penyelidikan mereka dan proses-proses \\
mengevaluasi proses & yang mereka gunakan. \\
pemecahan masalah & \multicolumn{2}{c}{} \\
\hline
\end{tabular}




\section{Pelaksanaan Pelajaran Berdasarkan Masalah}

Beberapa prinsip pembelajaran sama dengan prinsip-prinsip yang telah diberikan untuk pembelajaran langsung dan pembelajaran kooperatif, namun ada prinsip-prinsip lain yang unik untuk PBI.

a. Tugas-tugas Perencanaan

PBI dicirikan oleh siswa bekerja dalam pasangan atau kelompok kecil untuk melakukan penyelidikan masalah-masalah kehidupan nyata yang belum terdifinisi dengan baik, karena hakekat interaktifnya, PBI membutuhkan upaya perencanaan yang banyak bahkan lebih banyak dari model-model pembelajaran lain yang berpusat pada siswa. Dengan perencanaan guru itulah yang memudahkan pelaksanaan berbagai fase pelajaran PBI dan pencapaian tujuan pembelajaran yang diinginkan.

1. Penetapan Tujuan

Pertama kali kita mendeskripsikan bagaimana pembelajaran berdasarkan masalah direncanakan untuk membantu mencapai tujuantujuan seperti keterampilan menyelidiki, memahami peran orang dewasa, dan membantu siswa menjadi pebelajar yang mandiri. Dalam pelaksanaannya pembelajaran berdasarkan masalah bisa saja diarahkan untuk mencapai tujuan-tujuan yang telah disebutkan tadi.

2. Merancang Situasi Masalah

Beberapa guru dalam pembelajaran berdasarkan masalah lebih suka memberikan siswa suatu keleluasaan dalam memilih masalah untuk diselidiki karena cara ini meningkatkan motivasi siswa. Situasi masalah yang baik seharusnya autentik, mengandung teka-teki, dan tidak terdifinisikan secara ketat, memungkingkan kerja sama, bermakna bagi siswa, dan konsisten dengan tujuan kurikulum.

3. Organisasi Sumber Daya dan Rencana Logistik

Dalam pembelajaran berdasarkan masalah siswa dimungkinkan bekerja dengan beragam material dan pralatan, dan pelaksanaanya bisa dilakukan di dalam kelas, bisa juga dilakukan di perpusatakaan atau di laboratorium, bahkan dapat dilakukan di luar sekolah. Oleh karena itu, tugas mengorganisasikan sumber daya dan merencanakan kebutuhan untuk penyelidikan siswa haruslah menjadi tugas perencanaan yang utama bagi guru yang menerapkan model pembelajaran berdasarkan masalah. 
b. Tugas Interaktif

1. Orientasi siswa pada masalah

Siswa perlu memahami bahwa tujuan pembelajaran berdasarkan masalah adalah tidak untuk memperoleh informasi baru dalam jumlah besar, tetapi untuk melakukan penyelidikan terhadap masalah-masalah penting dan untuk menjadi pebelajar yang mandiri. Cara yang baik untuk menyajikan masalah untuk sebuah pelajaran dalam pembelajaran berdasarkan masalah adalah dengan menggunakan kejadian yang mencengangkan misteri dan suatu keinginan untuk memecahkan masalah.

2. Mengorganisasikan siswa untuk belajar

Pada model pembelajaran berdasarkan masalah dibutuhkan pengembangan keterampilan bekerja sama diantara siswa dan saling membantu untuk menyelidiki masalah secara bersama. Berkenaan dengan hal itu, siswa memerlukan bantuan guru untuk merencanakan penyelidikan dan tugas-tugas pelaporan. Bagaimana mengorganisasikan siswa ke dalam kelompok belajar kooperatif juga berlaku untuk mengorganisasikan siswa ke dalam kelompom pembelajaran berdasarkan masalah.

3. Membantu penyelidikan mandiri dan kelompok

- Guru membantu siswa dalam pengumpulan informasi dari berbagai sumber, siswa diberi pertanyaan yang membuat mereka memikirkan masalah dan jenis informasi yang dibutuhkan untuk pemecahan masalah. Siswa diajar menjadi penyelidik yang aktif dan dapat digunakan metode yang sesuai untuk masalah yang dihadapinya, selain itu diajarkan etika penyelidikan yang benar

- Guru mendorong pertukaran ide secara bebas dan penerimaan sepunuhnya ide-ide itu merupakan hal yang penting sekali dalam tahap penyelidikan pembelajaran berdasarkan masalah. Selema tahap penyelidikan guru memberi bantuan yang dibutuhkan tanpa mengganggu siswa

- Puncak proyek-proyek pembelajaran berdasarkan masalah adalah penciptaan dan peragaan artifak seperti laporan, foster, modelmodel fisik, dan videotape. 
4. Analisis dan evaluasi proses pemecahan masalah

Tugas guru pada tahap akhir pembelajaran berdasarkan masalah adalah membantu siswa menganilisis dan mengevaluasi proses berpikir mereka sendiri, dan keterampilan penyelelidikan yang mereka gunakan.

\section{Kaitan Pembelajaran Berdasarkan Masalah dengan Kemampuan Pemahaman dan Representasi Matematik}

Representasi sangat berperan dalam upaya mengembangkan dan mengoptimalkan kemampuan matematika siswa. Ketika siswa dihadapkan pada suatu situasi masalah matematika dalam pembelajaran di kelas, mereka akan berusaha memahami masalah tersebut dan meyelesaikannya dengan cara-cara yang mereka ketahui. Cara-cara tersebut sangat terkait dengan pengetahuan sebelumnya yang sudah ada yang berhubungan dengan masalah yang disajikan. Salah satu bagian dari upaya yang dapat dilakukan siswa adalah dengan membuat model (representasi) dari masalah tersebut. Representasi yang dibuat bisa bermacam-macam tergantung pada kemampuan masing-masing individu dalam menginterpretasikan masalah yang ada. Berdasarkan penjelasan sebelumnya sangat jelas bahwa pembelajaran berdasarkan masalah menjadikan siswa aktif, berpikir, megetahui berbagai hubungan antara tema-tema dan konsep-konsep bukan hanya sekedar menghafal dan membaca fakta secara berulang-ulang dan mendengarkan ceramah dari guru.

Oleh karena itu pembelajaran berdasarkan masalah memberikan kesempatan yang cukup bagi siswa untuk dapat melatih dan mengembangkan kemampuan pemahaman dan representasi matematiknya.

\section{SIMPULAN}

Berdasarkan uraian di atas maka dapat disimpulkan beberapa hal berikut:

a. Pembelajaran berdasarkan masalah mengorganisasikan pengajaran disekitar pertanyaan dan masalah, berfokus pada keterkaitan antar disiplin, penyelidikan, kerjasama, dan menghasilkan karya.

b. Pengetahuan yang mendasarkan pada PBI adalah kaya dan kompleks. Model pembelajaran ini membantu siswa mengembangkan keterampilan penyelidikan, memperoleh pengalaman tentang peran orang dewasa, dan meningkatkan rasa percaya diri dalam kemampuan berfikir. 
c. Sintaks PBI terdiri dari 5 tahap yaitu: mengorientasikan siswa pada masalah, mengorganisasikan siswa untuk belajar, membimbing penyelidikan individual maupun kelompok, mengembangkan dan menyajikan karya, dan menganalisis dan mengevaluasi kerja.

d. Tugas-tugas prapengajaran yang berkaitan dengan PBI terdiri dari mengkomunikasikan tujuan secara jelas, merancang situasi masalah yang menarik dan sesuai, dan melakukan persiapan alat dan bahan.

e. Guru bertindak sebagai fasilitator dan membimbing siswa melakukan penyelidikan.

\section{DAFTAR PUSTAKA}

Asup, S. (2004). Pembelajaran berbasis masalah untuk mengembangkan kemampuan pemahaman dan representasi matematik siswa sekolah menengah pertama "studi eksperimen pada siswa salah satu SMP di Cirebon", http" / sps.upi.edu/v2/?page=abstrak\&option=tesis\&action= view\&id=029462

Depdiknas. (2005). Materi pelatihan terintegrasi "matematika"- Pengelolaan Pembelajaran Matematika, Jakarta.

Johnson, E. B. (2002). Contextual teaching and learning, Corwin Press, Inc. California.

Muslimin, I., \& Nur, M. (2005). Pengajaran berdasarkan masalah, University Press, Surabaya.

Tadjab. (1992). Ilmu jiwa pendidikan, Karya Abditama, Surabaya.

TIM MKPBM. (2001). Strategi pembelajaran matematika kontemporer, JICA-UPI, Bandung. 